\title{
PANDANGAN MUHAMMAD SAID AL-ASYMAWI TENTANG RELASI AGAMA DAN POLITIK
}

\author{
Abdillah Halim \\ Institut Agama Islam (IAI) Ngawi \\ abdillahhalim@iaingawi.ac.id
}

\section{Abstract}

Nation building requires a cultural basis and platform as a basis for solidarity. In countries where the majority of the population is Muslim, religious aspirations and political movements must emerge. Certain strategies and handling are needed so that these Islamic aspirations are not counterproductive to national development. Muhammad Said AlAsymawi's view on the relationship between religion and politics contributes a lot of understanding and clarification and becomes an important exemplar of the dynamics of thought so that figh siyasa rediscovers its relevance in the contemporary world. For Muhammad Said Al-Asymawi, Muslims need a fear of secularization in the sense of placing religion and politics in their respective places so that religion can manifest in life without being manipulated and reduced by politics. To arrive at this need requires a complete and adequate understanding of what he calls authentic Islam. His mastery of Islamic treasures and the history of Islamic development, makes his views on the relationship between Islam and politics difficult to refute and dispels the stigma of some people that he is a liberal thinker. Muhammad Said Al-Asymawi offers a scientific and authentic perspective on siyasa figh and makes siyasa fiqh actual and relevant again in the current situation and conditions..

Keywords: Islam, Politics, Sharia

\section{Abstrak}

Nation building membutuhkan dasar budaya dan pflatform sebagai basis solidaritas. Di Negara-negara di mana mayoritas penduduknya adalah 
muslim, aspirasi dan gerakan politik bernuansa agama pasti mengemuka. Diperlukan strategi dan penanganan tertentu agar aspirasi keIslaman tersebut tidak kontraproduktif terhadap pembangunan kebangsaan. Pandangan Muhammad Said Al-Asymawi tentang relasi antara agama dan politik menyumbang banyak pemahaman dan klarifikasi dan menjadi eksemplar penting dinamika pemikiran agar fiqih siyasah menemukan kembali relevansinya di dunia kontemporer. Bagi Muhammad Said AlAsymawi, umat Islam membutubkan secaman sekularisasi dalam arti menempatkan agama dan politik pada tempatnya masing-masing sehingga agama dapat mengejawantah dalam kehidupan tanpa dimanipulasi dan direduksi oleh politik. Untuk sampai kepada kebutuhan tersebut diperlukan pemahaman yang utuh dan memadai terhadap apa yang dia sebut sebagai Islam yang otentik. Penguasaannya terhadap khazanah Islam dan sejarah perkembangan Islam, menjadikan pandangannya terkait relasi antara Islam dan politik sulit dibantah dan menepis stigma sebagian orang bahwa dia adalah pemikir liberal. Muhammad Said Al-Asymawi menawarkan cara pandang yang ilmiah dan otentik terkait fiqih siyasah dan menjadikan fiqih siyasah kembali aktual dan relevan pada situasi dan kondisi sekarang.

Kata kunci: Islam, Politik, Syariah

\section{PENDAHULUAN}

Pembangunan kebangsaan (nation-building) adalah upaya membangun pondasi dan pilar kehidupan kita dalam berbangsa dan bernegera. Nation Building dalam hal ini lebih dipahami sebagai pembangunan karakter kebangsaan sehingga keberadaan dan jati diri bangsa menjadi kokoh dan dinamis, di mana segenap warga bangsanya dapat bekerjasama mencapai cita-cita bersama. Bagi bangsa yang terdiri dari multi etnis dan multi budaya, pembangunan kebangsaan dapat didasarkan kepada dua hal, yaitu budaya masyarakat yang dominan, dan dapat pula didasarkan kepada platform atau common demoninator baru yang disepakati oleh semua warga bangsa. ${ }^{1}$ Budaya yang dominan atau platform baru tersebut selanjutnya menjadi identitas dan basis solidaritas yang memungkinkan kerja sama dalam rajutan rasa saling percaya di antara sesama warga bangsa. Untuk konteks keindonesiaan, ada dua entitas yang dapat digunakan sebagai dasar pembangunan kebangsaan yaitu budaya kenusantaran dan platform baru yang terdiri dari pilar dan

${ }^{1}$ Will Kymlicka, Politics in the Vernacular: Nationalism, Multiculturalism, and Citizenship (Oxford: Oxford University Press, 2001), 2. 
pondasi kebangsaan yang telah disepakati oleh para pendahulu republik ini. Dalam dimensi budaya kenusantaraan tersebut unsur Islam sebagai agama kelompok mayoritas memainkan peran penting. Kita beruntung, Islam yang berkembang di Nusantara adalah Islam dengan karakteristik-karakteristik tertentu yang dalam banyak hal mendukung upaya pembangunan kebangsaan. Karakteristik Islam tersebut adalah pertama, Islam yang dikembangkan lewat kebudayaan bukan politik lebih-lebih kekerasan; kedua, Islam yang mendapat pengayaan budaya tanpa harus kehilangan otensitasnya; ketiga, Islam tumbuh bersama budaya masyarakatnya yang sangat beragam; keempat, keberadaan negara kesatuan republik Indonesia berdasarkan Pancasila; kelima, keberadaan organisasi keagamaan arusutama yang memegang erat prinsip moderasi beragama dan pengamalan agama secara otentik; dan keenam, adanya peran Negara untuk mendorong dan memperkuat barisan moderasi beragama arusutama tersebut. ${ }^{2}$ Meskipun demikan, di Indonesia ada gerakan dan aspirasi Islam politik yang meskipun minoritas namun memiliki mobilasi sumberdaya yang baik sehingga gerakan dan aspirasinya seringkali bersifat kontraproduktif terhadap upaya pembangunan kebangsaan.

Gerakan dan aspirasi Islam politik tumbuh disebabkan oleh banyak faktor, selain faktor geopolitik dan geoekonomi, sebagian tentu saja oleh faktor pemahanan keagamaan tertentu. Tidak banyak pemikir Islam yang punya minat dan perhatian besar untuk menelaah dan mengkritik Islam politik di dunia muslim, terutama dari sudut pandang fiqih siyasah. Bahwa harus diakui bahwa pemahaman tentang kaitan antara agama dan politik, memerlukan kajian yang mendalam kepada sejarah dan sumber-sumber otoritatif ajaran Islam. ${ }^{3}$ Artikel ini memilih pandangan Muhammad Said Al-Asymawi tentang relasi antara agama dalam hal ini Islam dan politik. Tidak hanya menulis tentang Islam politik dan bagaimana mengatasi beragam soal yang melingkupinya, Muhammad Said Al-Asymawi juga terlibat aktif dalam beberapa upaya advokasi terhadap gerakan dan aspirasi Islam otentik versus gerakan dan aspirasi Islam politik di Mesir. Dalam rangka melindungi agama

2 Azyumardi Azra, "Distinguishing Indonesian Islam: Some Lesson to Learn" dalam Jajat Burhanudin dan Kees Van Dijk (ed.), Islam in Indonesia: Contrasting Images and Interpretations (Amsterdam: Amsterdam University Press, 2013)

3 Abdillah Halim, Fatwa Dan Politisasi Agama (Analisis Wacana Penggunaan Fatwa Pada Pilkada DKI Jakarta), An-Nuha: Jurnal Kajian Islam, Pendidikan, Politik, Budaya Dan Sosial Vol. 5 No.2 Desember 2018, 231-259 
dari distorsi dan manipulasi, dia banyak menulis dan berbicara tentang bagaimana memahami hubungan yang benar antara agama (Islam) dan politik, yakni bahwa agama harus kembali direvitalisasi tugas sucinya untuk memberi bimbingan moral dan spiritual menuju kebaikan dan kemanfaatan untuk sesama. ${ }^{4}$ Sementara politik harus sebisa mungkin diletakkan pada porsinya sebagai alat agregasi kekuasaan dan kepentingan yang kadang bahkan sering tidak sejalur dengan doktrin agama. Ini semua bermula dari keprihatinan dia terhadap pemikiran dan gerakan Islam politik yang membodohi umat dan malah membuat mereka semakin terpuruk. Umat Islam, lewat pemikirannya, diajak kembali kepada keinsyafan terhadap nilai-nilai Islam yang otentik. Tidak hanya itu umat juga diajak untuk memahami Islam secara metodologis sehingga memeroleh pengetahuan yang benar, bermakna, dan bermanfat, terutama tentang kaitan antara Islam dan politik. Muhamamd Said Al-Asymawi layak dijadikan sebagai eksemplar rujukan penting terkait pemikran dan fqih siyasah kontemporer.

\section{KIPRAH INTELEKTUAL \& AKTIVISME MUHAMMAD SAID AL-ASYMAWI}

Putera dari Muhammad Al-Asymawi ini dilahirkan pada tahun 1932 di Mesir. Muhammad Said Al-Asymawy tamat dari Fakultas Hukum Universitas Kairo pada tahun 1954 dan menjadi asisten jaksa Propinsi Alexandria pada tahun yang sama. Pada tahun 1956 dinaikkan jabatannya menjadi jaksa Provinsi Alexandria. Pada tahun 1961 Muhammad Said AlAsymawy menjadi hakim dan lantas jaksa ketua pada 1971. Pada 1974 menaik Iagi jabatannya menjadi jaksa ketua propinsi Kairo Tengah. Selain itu, pada tahun 1977, Muhammad Said Al-Asymawy juga direkrut menjadi penasehat negara untuk pembuatan undang-undang. Pada 1978 me Muhammad Said Al-Asymawy njabat hakim Mahkamah Mesir dan kemudian menjadi ketuanya. Dari sini kariernya terus melejit hingga menjadi Ketua Mahkamah Pidana dan Ketua Mahkamah Keamanan Negara, sebuah pengadilan khusus yang menangani kasus-kasus subversif dan perlawanan terhadap negara, pada 1981. Sebelumnya pada 1978 Muhammad Said Al-Asymawy sempat pula melanjutkan studinya di Harvard Law School Amerika Serikat. Jabatan yang terakhir kali Muhammad Said Al-Asymawy pegang adalah anggota Kejaksaan Agung Mesir dan pensiun pada Juli 1993. Sedari pensiun dan

4 Wasisto Raharjo Jati, AGAMA DAN POLITIK: Teologi Pembebasan Sebagai Arena Profetisasi Agama, Walisongo, Volume 22, Nomor 1, Mei 2014, 133-156 
hingga sekarang, Muhammad Said Al-Asymawy tetap bermukim di Kairo, tepatnya di jalan Ciezira No. 9 Apartemen 19 di kawasan Zamalek, sebuah kawasan elit tempat tinggal para diplomat Arab di Mesir. ${ }^{5}$

Di samping sebagai pejabat pemerintah, Muhammad Said Al-Asymawy juga dikenal luas sebagai intelektual yang memiliki keahlian dalam bidang hukum Islam (syari'at), ushuluddin, perbandingan agama dan perbandingan hukum. Kiprah intelektual Muhammad Said Al-Asymawy dibuktikan lewat ceramah dan kuliah-kuliahnya di berbagai seminar dan universitas, baiknasional maupun internasional. Muhammad Said Al-Asymawy pernah mengisi kuliah di American University di Kairo, Harvard University, Princeton, Tempel, Marshall, Barke/ey; Leiden, Sorbone dan beberapa perguruan tinggi Iain di Eropa. ${ }^{6}$ Kecendekiawanan Muhammad Said Al-Asymawy tampaknya tak bisa dipungkiri. Dia telah melahirkan banyak sekali buku. Buku-bukunya yang pernah dipublikasikan adalah: Mission of Existence, terbit pada 1958 dan edisi bahasa Arabnya terbit pada 1977 dengan judul Risalah al-Wujud;Tarikh al-Wujudiyah al-Fikr al-Basyari, terbit pada 1963; Conscience of the Age, terbit pada 1968 dan edisi bahasa Arabnya terbit pada 1979 dengan judul Damir al-Ashr; Hasid al-Ayl, terbit pada 1974; Usul asySyari'ah, terbit pada 1979, buku ini telah diterjemahkan ke dalam bahasa Inggris dengan judul Roots of Islamic Law dan telah pula dialihbahasakan ke dalam bahasa Indonesia dan diterbitkan Oleh penerbit LKiS Yogyakarta dengan judul Nalar Kritis Syariah pada Januari 2004; Jawharul-lslam, terbit pada 1984; Ruh al-Adalah, terbit pada 1986; AI-Islam as-Siyasiy, terbit pada 1987, bersama Ushul asy-Syari'ah, buku ini tergolong buku yang paling banyak diminati Oleh banyak intelektual dan khalayak pembaca secara umum, buku ini telah diterjemahkan ke dalam bahasa Inggris dengan judul Islam and Political Order dan ke dalam bahasa Perancis dengan judul L'Islamisme Contre L 'Islam, untuk pembaca Indonesia, penerbit Alifya Bandung telah menerbitkan edisi terjemahan bahasa Indonesianya dengan judul Menentang Islam Politik pada Mei 2004; Ar-Riba wa al-Faidah fi al-Islam, terbit pada 1988; Asy Syari'ah al-Islâmiyah wa al-Qanun al-Misriy, terbit

5 Who's Who in The Arab World. Biographycal Dictionary 1986-1987 (Beirut, Libanon : l'nblitec Publication bekerjasarna dengan Bntt.envorih And Co (Publisher) LTD Inggris, tt), 130,. lihat juga David Sagiv, Fundamentalism and Intelectuals in Fgypt 1971-1993 (London: Frank Cass, 1995), hlm. 71.

6 Muhammad Sa'id al-'Asymawi, UsuI asy-Syari'ah (Beirut: al-Maktabah al-Tsaqafiyyah, 1992), biogafi pengarang. 
pada 1988; Ma alim al-Isläm, terbit pada 1989; Al-Khilâfah al-Islämiyah, terbit pada 1990; Haqiqatu al-Hijâb wa Hujjiyatu al-Hadis, buku ini telah diterjemahkan ke dalam bahasa Indonesia dengan judul Kritik atas Jilbab dan diterbitkan pada Pebruari 2003 oleh JIL Jakarta.'

Selain buku-buku di atas ada beberapa buku Muhammad Said Al-Asymawi yang lebih belakangan terbitnya. Buku-buku itu antara Iain Ruh ad-Din, Jawami' al-Fikr, Hayäh al-Insän, dan al-Islam al-Mustanir. Tidak hanya dalam bahasa Arab, Muhammad Said Al-Asymawi juga menulis beberapa buku dalam bahasa Inggris, buku-buku itu adalah Development of Religion, Islam and Religion, dan Militant Doctrine in Islam. Saat masih produktif, Muhammad Said Al-Asymawi tercatat juga sebagai pengisi kolom tetap majalah mingguan Mesir Rose el-Yusuf dan October Magazine. Sebagian dari bahan-bahan kuliah yang pernah disampaikannya di universitasuniversitas di Eropa, Amerika Serikat, Kanada, India dan Timur Tengah, oleh Carolyn Fluehr-Lobban, seorang guru besar hukum dan ilmu politik Universitas Florida dan sahabat karib Muhammad Said Al-Asymawy, diedit dan dikumpulkan menjadi sebuah buku dengan judul Against Islamic Extremism dan diterbitkan pada 1998. Buku ini pun telah diterjemahkan ke dalam bahasa Indonesia dan diterbitkan oleh penerbit Desantara Depok pada Nopember 2002 dengan judul Jihad Melawan Islam Ekstrem.

Saat menjabat hakim, Muhammad Said Al-Asymawi pernah bertindak sebagai hakim ketua yang mengadili gerakan Jama'ah Jihad, tepatnya pada tahun 1981, dan kaum Nasiris. ${ }^{7}$ Jamaah Jihad adalah salah satu dari beberapa gerakan Islam yang berupaya menggulingkan pemerintahan yang sah dan menolak mentah-mentah sistem demokrasi. Anggota Jama'ah Jihad pulalah yang membunuh Presiden Anwar Sadat pada 3 Oktober 1981, saat sang Presiden tengah meninjau parade militer memperingati Perang 1973. Sebelumnya, pada tahun 1970-an, Muhammad Said Al-Asymawi secara keras menentang upaya Presiden Anwar Sadat untuk menimbang Proposal Konstitusi Islam. Proposal Konstitusi Islam tersebut diajukan oleh gerakangerakan Islam Mesir yang berkeinginan menjadikan Mesir sebuah negara Islam yang total. Upaya itu dinilai Muhammad Said Al-Asymawi akan melahirkan pembedaan dan peminggiran terhadap kelompok Islam dan masyarakat yang lain terutama warga non-muslim, yakni minoritas Kristen Koptik. Muhammad Said Al-Asymawi selanjutnya berpendapat bahwa hubungan antara individu dan negara adalah hubungan kewarganegaraan,

7 David Sagiv, Fundamentalism and Intelectuals, 71. 
bukan keagamaan. ${ }^{8}$ Tulisan-tulisan Muhammad Said Al-Asymawi juga dinilai turut menghentikan gerakan politik pada awal 1980-an yang berusaha keras melakukan kodifikasi hukum Islam (syari'at) sebagai satu-satunya hukum negara yang berlaku di Mesir. ${ }^{9}$

Muhammad Said Al-Asymawi berulang kali mengkritik sikap pemerintah Mesir yang diskriminatif terhadap umat Kristen dan gereja Koptik. Muhammad Said Al-Asymawi mengritisi sebuah aturan yang telah berumur 139 tahun yang mensyaratkan adanya keputusan Presiden untuk membangun atau memugar sebuah gereja, dan pembangunan gereja tersebut tersebut harus melalui peninjauan sepuluh tahapan, termasuk evaluasi dampak pembangunan itu terhadap irigasi di sekitar gereja, rel kereta api, dan umat Islam di sekitarnya, sementara di sisi Iain, pembangunan sebuah masjid hanya memerlukan satu ijin teknis yang sangat gampang bersamaan dengan kenyataan bahwa sejak tahun 1970 telah berdiri 30.000 masjid baru tanpa ada ijin sama sekali. ${ }^{10}$

Sepeninggal Presiden Sadat, usaha-usaha yang dilancarkan oleh gerakan-gerakan Islam garis keras tak kunjung habis, bahkan kian menjadi di era Husni Mubarak. Mereka kini mulai mengincar para tokoh maupun intelektual yang berusaha membendung gerakan mereka. Tokoh-tokoh yang menyuarakan demokrasi, persamaan, pemisahan agama dan negara, dan nilai-nilai Islam yang lebih substansial mereka intai untuk dihabisi. Aksi mereka berpuncak pada pembunuhan mereka terhadap Faraj Foda, seorang kolumnis pengecam fundamentalisme Islam, pada Juli tahun 1992. Peristiwa pembunuhan Faraj memaksa aparat kepolisian Mesir untuk memberi perlindungan 24 jam penuh kepada Muhammad Said Al-Asymawi. yang juga sebagai sasaran pembunuhan. ${ }^{11}$ Sebenarnya ancaman terhadap Muhammad Said Al-Asymawi telah dilancarkan sejak terbitnya buku beliau yang telah berusaha menampilkan Islam secara "lain" dan lebih substansial, yakni Usul asy-Syari'ah pada 1979. Muhammad Said Al-Asymawi secara terus-menerus mendapat perlindungan pemerintah sejak 1980, selama 13 tahun saat

8 Carolyn Fluehr-Lobban, "Melawan Ekstremisme Islam, Kasus Muhammad Sa'id alAsymawi”, pengantar editor untuk Muhammad Sa'id al-Asymawi, Jihad Melawan Islam Ekstrem, terj. Haryanto Azumi (Depok: Desantara, 2002), 22.

9 Ibid., 14.

${ }^{10}$ Ibid, 9.

${ }^{11}$ John L. Esposito dan John O. Voll, Demokrasi di Negara-Negra Muslim: Problem \& Prospek, terj. Rahamni Astuti (Bandung: Mizan, 1999), 245. 
menjabat hakim, dan juga sejak dia pensiun pada tahun 1993. Pada Januari tahun 1992, ada upaya dari para Syeikh al-Azhar untuk mencekal lima buah bukunya (termasuk Usul Asy Syari'ah) dari pemeran buku paling bergengsi di Mesir, Cairo International Book Fair. Namun karena Muhammad SaidAlAsymawi masih menjabat sebagai Ketua Mahkamah Mesir, Presiden Husni Mubarak melakukan intervensi dan pencekalan tersebut dibatalkan. ${ }^{12}$

Setelah pensiun, komitmen Muhammad Said Al-Asymawi terhadap demokrasi, kemerdekaan berpikir \& hak-hak minoritas tampaknya tak kendur. Pada 1995, secara terang-terangan Muhammad Said Al-Asymawi mengeritik Keputusan Pengadilan Banding Mesir yang memurtadkan Nasr Hamid Abu Zaid, scorang guru beşar Universitas Kairo yang belakangan terkenal karena pandangan-pandangannya terhadap al-Qur'an dan konsep nash. Sebagai konsekuensinya, Nasr Hamid diharuskan menceraikan istrinya dan terusir ke negeri lain (Belanda). ${ }^{13}$ Mengenai keputusan yang menyangkut Nasr Hamid ini, sebagaimana dikutip oleh Carolyn, dia mengatakan, "Keputusan ini sangat berbahaya, sebab akan mendorong orang untuk menggugat setiap penulis atau intelektual yang berani bicara jujur melawan mereka yang ekstrem. Kawan ekstrem telah menyusup ke dalam lembaga peradilan. Pemerintah tahu akan hal itü tapi tidak berupaya mencegahnya. Saya ragu kalau lembaga peradilan bisa, sungguh-sungguh bersikap netral". ${ }^{14}$ Sebelumnya pada 1994, Muhammad Said Al-Asywawi telah pula menerima piagam penghargaan dari Komite Pengacara untuk HAM. Penghargaan itu diberikan atas karya-karya beliau yang dinilai mempromosikan perlindungan HAM dan rule of law. ${ }^{15}$ Namun Muhammad Said Al-Asymawi bukanlah tokoh yang lepas sama sekali dari kesalahan, pada 25 Januari 1992, selaku hakim ketua, dia telah memutuskan hukum 8 tahun kepada Alaa Hamid. Novel Alaa Hamid yang berjudul Sebuah Jarak dalam Pikiran Manusia dinilai oleh majelis hakim telah merongrong agama. Padahal menurut kalangan liberal Mesir, novel tersebut sebagai ekspresi kemerdekaan berpikir adalah legal dan dari segi isi sebetulnya mengajak orang untuk melampau kejumudan pemikiran. ${ }^{16}$

\footnotetext{
${ }^{12}$ Carolyne Fluehr Lobban, "Melawan Ekstremisme Islam, Kasus Muhammad Said alAsymawi”. 6.

${ }^{13}$ Ibid., 3.

${ }^{14}$ Ibid., 12.

15 Ibid., 16.

${ }^{16}$ Kasus ini lepas dari pengamatan para peminat pemikiran dan ketokohan Al-Asymawi.
} 


\section{PANDANGAN MUHAMMAD SAID AL-ASYMAWI TENTANG RELASI AGAMA \& POLITIK}

Sebelum menjelaskan lebih jauh tentang relasi agama dan negara, Muhammad Said Al-Asymawi menyatakan bahwa konsep teokrasi memiliki tiga fitur yang saling berhubungan, yaitu, pertama, penguasa adalah manifestasi dan pancaran dari Tuhan; kedua, kekuasaan penguasa adalah bentuk takdir atau ketentuan Tuhan; dan ketiga, di dalam diri penguasa melekat hak-hak ketuhanan. Hal ini tidak terlepas dari sejarah agama-agama besar di dunia di mana agama-agama tersebut mengambil sikap terhadap politik dalam tiga tipe, pertama, pendiri agama, Nabi atau guru, memerintah sendiri, menentukan perkara-perkara agama sekaligus menetapkan kebijakan-kebijakan politik, sebagaimana yang terjadi pada Yahudi dan Islam; kedua, pendiri agama, Nabi atau Guru, melepaskan diri dari politik, setelah itu para penerusnya mendirikan lembaga gereja yang dalam riwayatnya kemudian bersinggungan dengan politik, sebagaimana pada Kristen; ketiga, pendiri agama, Nabi atau Guru, lepas dari kekuasaan politik, dan setelah itu para penerusnya pun mencegah diri mereka untuk mendirikan lembaga apapun agar agama tidak dimanipulasi oleh politik, semisal yang terjadi di Budha. ${ }^{17}$

Yang terjadi dalam Islam Nabi Muhammad SAW ditempatkan oleh umatnya sebagai Nabi, penguasa, sekaligus hakim. Setelah beliau wafat, kekuasaan dipegang oleh para khalifah, pemimpin yang datang dan berkuasa setelah beliau. Para khalifah 4 sepeninggal Nabi masih terhitung arif dan bijak dalam memaknai kekhalifahan, ini yang tidak terjadai setelah itu, di mana para khalifah mengklaim seabagai pengganti Nabi dalam semua kapasitasnya secara mutlak: mereka memaknai kekhalifahan sebagai kekuasaan agama sekaligus kekuasaan politik yang kebal terhadap kritik dan tidak mengenal batas. Dalam pada itu, ulama lanats terbagi menjadi tiga kelompok, yakni pembela rezim secara membabi buta, ulama yang menarik jarak dan mengkritisi rezim, dan ulama yang sama sekali mengasingkan diri dari semua hal yang bernuansa politik. Tipe kedua melahirkan konsep dua kota (the idea of two cities): kota Tuhan (civitas dei) yang diperintah oleh

Untuk informasi terkait peristiwa penghukuman Alaa Hamid oleh Mahkamah Mesir yang diketahui Asymawi ini silahkan baca Goenawan Mohammad, "Kaca", catatan pinggir 4 (Jakarta: Grafiti, 1999), 119.

${ }_{17}$ Muhammad Said Al-Asymawi, Jihad Melawan Islam Ekstrem, terj. Hery Haryanto Azumi, (Depok: Desantara, 2002), 107-109. 
gereja dan civitas terrena, kota sipil yang diperintah oleh kelompok feudal. Pada awalnya gereja memegang kontrol terhadap feudal akan tetapi pada masa tertentu feudal berganti mengendalikan gereja sehingga terjadi ketegangan di antara keduanya. Ketegangannya semakin memuncak ketika kekuasaan feudal digantikan oleh kekuasaan para pemodal dan pemilik industri. Ketegangan ini coba diselesaikan lewat sekularisme, pemisahan antara agama dan politik. ${ }^{18}$

Dalam pandangan Muhammad Said Al-Asymawi, sekularisme dalam arti pemisahan agama dari politik, perlu dan dibutuhkan di antaranya untuk melindungi agama dari distorsi dan manipulasi politik. Agama harus dijaga sebagai keimanan dan etika yang menghormoniskan hubungan antara individu, keluarga, masyarakat, dan alam semesta. Ketika agama bertaut dengan politik, ia rentan menjadi ideologi yang ekslusif, menjadikan pemeluknya politisi atau petugas partai. Dalam sekularisme, yang berkuasa adalah civil code atau hukum sipil, di mana tindakan penguasa harus dipandang sebagai tindakan sipil dan bukan tindakan keagamaan, sehingga terbuka bagi kritik dan kontrol warga, sungguhpun tindakan tersebut diklaim digerakkan oleh iman maupun pandangan agama. Sekularisasi dalam hal ini adalah bentuk pengaturan agama dan politik agar tetap dalam posisinya masing-masing, tidak dikacaukan maupun dicampur aduk sehingga menimbulkan banyak persoalan, bukan penghilangan peran dan fungsi agama dan agamawan. ${ }^{19}$

Di samping itu, lanjut Muhammad Said Al-Asymawi, sekularisasi mencegah agama digunakan sebagai wahana sektarianisme yang dipicu oleh tribalisme, rasisme, dan aspek religiopolitik. Kelompok dan lembaga religiopolitik, didasari oleh tribalisme dan rasisme, jatuh pada sektarianisme karena empat hal, pertama, mereka tidak memahami iman mereka sendiri maupun iman orang lain, pemahaman mereka tertutup oleh slogan, distorsi, dan bayang-bayang mereka sendiri, sehingga di satu sisi mereka tidak memahami iman mereka sendiri dan di sisi yang lain memusuhi iman kelompok lain; kedua, lembaga religiopolitik mengubah iman menjadi dogma yang kaku dan eksklusif, dan pada titik yang ekstrem menjadi iman sebagai alat memerangi entitas yang berbeda; ketiga, kelompok religiopolitik banyak yang menyimpang dari doktrin dan ajaran otentik agamanya sehingga tidak beriman dengan iman dan pemahaman yang benar, dan bersamaan dengan

${ }^{18}$ Ibid., 110.

${ }^{19}$ Ibid., 112-113. Lihat Juga Muhammad Azhar, Etika Politik Mohammed Arkoun, Ishraqi, Vol. 10, No. 1, Juni 2012 
itu, cenderung memandang adanya kekafiran atau kesesatan pada iman/ agama kelompok lain; keempat, kelompok religiopolitik sering membatasi kode etik hanya pada kelompoknya sendiri, dan tidak memberlakukan kode etik tersebut kepada entitas religiopolitik yang berbeda. Agama dan iman ketika dirubah menjadi lembaga religiopolitik akan kontraproduktif terhadap upaya menjadikan iman dan agama sebagai penyambung dan pemersatu antarumat manusia. ${ }^{20}$

Pentingnya sekularisasi di internal Islam sebagaima dimaksud di atas, juga dilandasi oleh telaah kritis terhadap keberadaan politik dan pemerintahan pada generasi Islam, telaah yang mampu menunjukkan kekhasan dan karakter obyektif masing-masing. Nabi SAW adalah seorang pendakwah dan bukan penguasa ketika berdomisili di Mekkkah. Dia menjadi penguasa tatkala sudah hijrah dan berdomisili di Madinah. Ada dua karakter menonjol pemerintahan Nabi SAW di Madinah. Pertama, pemerintah Nabi SAW di Madinah bukanlah bentuk pemerintahan yang ketat dan rinci sebagaimana pemerintahan dalam terma modern, melainkan hanya sebatas soal penegakan dan administrasi prinsip keadilan. Kedua, pemerintahan Nabi SAW di Madinah adalah pemerintahan Allah, di mana Allah benar-benar mengontrol tindakannya sehingga jauh dari penyalahgunaan wewenang dan ketidakadilan. Konsekuensinya adalah klaim kelompok yang menyatakan bahwa pemerintahan Nabi SAW setara dengan pemerintahan dalam pengetian modern adalah tidak berdasar dan bahwa pemerintahan Nabi SAW tidak bisa diwariskan dan ditiru oleh generasi selanjutnya karena karakternya yang sangat khusus dan istimewa tersebut. Hal ini diperparah oleh para raja dan ulama Istana di internal Islam yang mendefinisikan khilafah sebagai pengganti fungsi kenabian yang dapat diwariskan secara turun-temurun. Fokus mereka adalah pada penguatan fungsi dan kedudukan khalifah sebagai penguasa pengganti Nabi dan jarang sekali berbicara terkait penguatan hak-hak rakyat diperintah. Para penguasa dalam hal ini hanya memikirkan kepentingan pribadi, keluarga, suku, dan kelompoknya. Akibatnya, diskusi tentang khilafah dalam dunia Islam adalah diskusi tentang pemerintahan suku-suku besar tertentu baik di Sunni maupun Syi'i dan bukan tentang kesempatan rakyat untuk secara bebas dan terbuka menentukan pemimpinnya. Perdebatan dalam fiqih siyasah sunny tentang apakah pemimpin harus dari Suku Quraiys atau dapat dari Non-Quraisy menjadi menonjol. Yang terjadi di syii juga sama, apakah imamah harus dari kalangan ahlul bait

\footnotetext{
${ }^{20}$ Ibid., 114-115.
} 
atau non ahlul bait telah membikin kelompok ini terpecah menjadi banyak sekte. Ditunjang pula oleh pemberlakuan Imamah sebagai pilar keimanan dan anggapan bahwa Imam tidak mungkin salah oleh kelompok. Khilafah kemudian identitk dengan jabatan politik suku Quraisy, Bani Umayah, Bani Abasiah, dan seterusnya di internal sunni atau privilese keluarga Nabi terutama dari jalur Fatimah dan Ali di internal syii. Ini menurut Muhammad Said Al-Asymawi menunjukkan bahwa khilafah dalam sejarahnya telah dipahami secara salah karena dipahami di luar semangat ajaran Islam yang menentang tribalisme dan menegaskan persamaan di antara umat manusia. ${ }^{21}$

Politik dengan ruh tribalisme menguat ketika Umayah memerintah, yakni ketika ia mengundang para fuqaha untuk melegitimasi politiknya dengan dalil agama. Dari sini muncul teori-teori fiqih siyasah yang terpengaruh besar oleh teori-teori kerajaan Eropa Abad Tengah, semacam doktrin bahwa khalifah bebas dari kesalahan, wakil tuhan, tidak wajib menjawab pengaduan warga, dan pemilik tunggal atas tanah dan kekayaan sebuah negeri. Hal semacam ini, menurut Muhammad Said Al-Asymawi, belum terjadi di era kekhalifahan empat awal. Di era itu, ajaran Islam yang otentik tentang politik masih dapat dipraktekkan secara baik di ruang publik. Teori politik kerajaan ini kemudian menjadi satu-satunya teori politik Islam yang dianggap benar meskipun beseberangan secara diametral dengan ajaran Islam yang otentik. Pemerintah Islam menjadi identik dengan kekuasaan absolut, tiadanya musyawarah dalam pengambilan keputusan, pendelegitimasiaan hak-hak rakyat, pengharaman secara mutlak oposisi, dan sebagainya. Yang selanjutnya terjadi tidak lain adalah perseteruan berdarah yang bersifat kontinyu antara khalifah keempat dengan Dinasti Umayah, Umayah dengan Syiah, Umayah dengan Abasiyah, maupun Abasiyah dengan Syiah. Setelah era kekhalifahan yang Empat berakhir, Islam berubah menjadi kekaisaran yang seringkal melakukan invasi dan penaklukan ke negeri-negeri lain dengan alasan yang murni politik dan ekonomi namun dibungkus dengan dalih dan slogan keagamaan. Di antara dalih agama yang digunakan untuk menginvasi negara lain itu adalah konsep tentang darul islam dan darul harb. Konsep ini menurut Muhammad Said Al-Asymawi tidak bersumber dari ajaran Islam yang otentik dan oleh karena itu harus dihapus karena menghalangi spirit Islam yang menyatukan antara spesies manusia di bawah panji kedamaian, kemanusiaan, dan kasih sayang. Tidak hanya itu, pemerintahan Islam sendiri memperlakukan warganya sebagai gembalaan, mengkontrol

${ }^{21}$ Ibid., 116-120 
kebudayaan dan pendidikan, membatasi pendidikan rakyat semata pada penghapalan Qur'an, Hadis, dan kaidah fiqih. Ini membuat tingkat buta huruf yang tinggi dan menutup akses warga kepada ilmu pengetahuan yang lain sehingga warga nyata-nyata tertinggal dari perkembangan jaman dan peradaban global. $^{22}$

Menghindarkan agama dari politisasi demi kepentingan kekuasaan, tribalisme, maupun ekonomi, Islam otentik tidak mengakomodir struktur politik khusus parsial semacam khilafah atau imamah dalam doktrin ayat Qur'an dan Hadis. Islam otentik menggariskan bahwa kekuasaan politik dan pemerintahan merupakan struktur yang diciptakan dan dikondisikan secara sosial sesuai dengan kebutuhan masyarakat dan semangat zaman dalam rangka mewujudkan nilai etis ajaran Islam tentang keadilan, persamaan, kasih sayang, dan kemanusiaan. Islam otentik menegaskan bahwa setelah pemerintahan Nabi, yang dikehendaki oleh Islam adalah pemerintahan rakyat, di mana rakyat memiliki kebebasan dan hak untuk menentukan, mengontrol, dan mengganti struktur politik secara damai dan rasional. Terma pemerintahan dalam Al-Qur'an pun, menurut Muhammad Said Al-Asymawi, lebih bermakna sebagai administrasi dan penegakan keadilan ketimbang "otoritas politik". Akan tetapi yang kemdian terjadi adalah tafsir pemerintahan sebagai otoritas politik lebih banyak disebakan oleh para khalifah dalam rangka meneguhkan kekuasaannya dan mengkontrol rakyat. Islam yang otentik tidak menghendaki pemerintahan agama karena karakternya yang manipulatif tersebut. Islam yang otentik memiliki kepedulian besar terhadap rakyat, dengan hati-nurani dan bukan dengan sistem, dengan pendekatan etis dan bukan dengan pendekatan hukum. Islam yang otentik menegaskan bahwa pemerintahan yang Islami adalah pemerintahan berbasis keadilan, yakni sebuah pemerintahan sipil oleh rakyat dan demik kemaslahatan rakyat. Pemerintahan yang islami adalah pemerintahan yang mengumpulkan semua warga dalam satu ikatan yang setara tanpa ada satu pun yang dieksklusikan. Pemerintahan islami adalah pemerintahan yang mendukung ilmu pengetahuan, seni-kebudayaan, dan kebebasan berpikir dan berekspresi warga negara. Pemerintahan yang islami adalah pemerintahan yang memahami dan mengkampanyekan Islam sebagai metode meraih kemajuan, jalan menuju tuhan, dan jalan kasih sayang. ${ }^{23}$

Menguatnya Islam politik yang dalam hal ini seruan untuk mendiri-

\footnotetext{
${ }^{22}$ Ibid., 121-124.

${ }^{23}$ Ibid., 125-126.
} 
ikan pemerintahan Islam didorong oleh banyak hal. Menurut Muhammad Said Al-Asymawi hal tersebut didorong oleh faktor faktor sebagai berikut: pertama, kolonialisme Prancis dan Inggris terhadap negara-negara muslim telah memicu dua respons yang berbeda: respons liberal berupa upaya mendirikan peradaban baru berbasis kebebasan dan humanism maupun respons islamis berupa tuntutan untuk menghidupkan kembali kekhalifahan Islam yang pernah jaya; kedua, berdirinya negera Pakistan dan Negara Israel memberi inspirasi kepada gerakan-gerakan Islam di wilayah lain untuk mengorganisir diri menuju terwujudnya sebuah masyarakat dan Negara berbasis identitas keagamaan; ketiga, pemerintahan militer dan semimilter di banyak negeri muslim sengaja mengaihkan perhatian warganya kepada ancaman Barat dan kelompok liberal dalam rangka membungkam kontrol dan oposisi warga terhadap rezim tersebut. Mereka mengeksploitasi ancaman tersebut sedemikian rupa sehingga warga menjadi antipasti terhadap segala yang berbau Barat dan liberal, padahal jalur dan pemikiran moderat dari kelompok liberal diperlukan oleh masyarakat untuk menjadi alat kritik dan pisau analisis. Jika ini ditutup, maka warga cenderung untuk menjadi konservatif dan xenopobis dan menumukan katalisator ekspresi mereka pada ekstremisme keagamaan. Keempat, merebaknya korupsi di banyak negara Islam karena tidak dikenalnya audit dan akuntabilitas direspons oleh kelompok Islamis dengan memobilisasi masa menyerukan perlunya penegakan pemerintahan yang islami, sebuah seruan yang sebenarnya tidak akan menyelesaikan masalah. Kelima, pemerintahan islam menggunakan slogan "kemerosotan Barat" untuk mengkampanyekan pentingnya pemerintahan Islam yang akan mewarisi peradaban setelah kemerosotan tersebut. Keenam, negara-negara kaya minyak memiliki peran besar dalam penyebaran identitas politik islam ke negeri negeri muslim yang lain, identitas tersebut menyumbang pengaruh besar pada dukungan terhadap posisi mereka sebagai role model pemerintahan Islami, di mana makna islami bagaimana yang seharusnya didakwahkan tidak lagi menjadi persoalan. ${ }^{24}$

Terlepas dari sebab-sebab yang mendasari lahirnya Islam politik, pemahaman yang benar terkait kedudukan Islam dan kedudukan politik serta makna syariah perlu dipopulerkan kembali. Di antaranya agar masyarakat muslim mendapat pengertian yang benar dan lepas dari agitasi dan propaganda kelompok Islam politik. Secara lebih detil Muhammad Said Al-Asymawi menjelaskan makna otentik syariah sebagai berikut: pertama,

${ }^{24}$ Ibid., $127-140$. 
syariah berarti metode, jalan, atau cara; kedua, jalan Islam adalah kasih sayang; ketiga, membatasi Islam sebagai nasionalisme berarti meninggalkan sesuatu yang mutlak demi sesuatu yang relatif dan meninggalkan agama demi chauvinism; keempat, membatasi syariah sebagai aturan hukum atau yurisprudensi berarti membatasinya pada tempat dan waktu tertentu; kelima, membatasi metode pada pendapat berarti mengkerdilkannya; keenam, kasih sayang berarti tidak membikin konfrontasi dengan Negara manapun; ketujuh, kasih sayang bermakna mengakui dan menghormati jalan lain: Yahudi, Kristen, Budha, Hindu, dan lain-lain; kedelapan, kasih sayang bermakna bekerjasama dengan setiap orang tanpa mempersoalkan asal usul agama, ras, dan kebudayaannya; kesembilan, kasih sayang bermakna merancang metode pemahaman baru untuk saling menghormati dan menghargai; kesepuluh, kasih sayang adalah menjaga umat manusia serta menggabungkan masa lalul, masa kini, dan masa yang akan datang dalam satu visi humanistik; kesebelas, kasih sayang mencari semangat teks bukan teksnya itu sendiri dalam rangka memanusiakan manusia; dan keduabelas, kasih sayang berarti menjadi rahmat untuk seluruh alam dengan menebar kemakmuran, keadilan, persamaan, dan cinta untuk seluruh manusia kapan saja dan di mana saja. ${ }^{25}$

Terhadap tuntutan untuk menegakkan "pemerintahan Islam", Muhammad Said Al-Asymawi mengajukan beberapa catatan kritis yang layak untuk dicermati. Pertama, jika yang dikehendaki dengan pemerintahan Islam adalah pemerintahan berdasarkan syariah, maka perlu diklrarifikasi dulu apa makna syariah yang dimaksudkannya. Syariah telah mengalami pengembangan makna, dari yang awalnya sebagai jalan yang telah ditetapkan Allah, kemudian diperluas menjadi segala ketentuan yang ada dalam Qur'an dan Sunnah, dan terakhir ia meliputi seluruh yurisprudensi Islam fa yang berkembang dalam sejaran dengan beragam variannya, maka syariah mana yang dimaksud dan yang dirujuk? Kedua, Jika pemerintahan Islam hanya mengacu kepada model ideal pemerintahan Nabi SAW di Madinah dan Sahabat Umar yang hanya sebuah fase sekilas dari rangkaian panjang sejarah umat Islam, maka bagaimana kita memahami fenomena-fenomena di fase-fase lain yang tidak ideal? Belum lagi soal pemerintahan Islam itu bersandar pada sistem dan kelembagaan atau sekedar kebaikan personal yang cenderung Insidental. Ketiga, jika pemerintahan Islam didefinisikan sebagai sistem pemerintahan yang bertujuan menegakkan keadilan, moral,

\footnotetext{
${ }^{25}$ Ibid., 142-143.
} 
dan mendakwahkan agama, maka system yang lain apa pun namanya harus juga diangap Islami sejauh ia bertujuan menegakkan keadilan, moral, dan mendukung syiar agama. Jika kita lihat dalam fenonema sejarah, banyak negara dan sistem politik yang tumbang lantaran menolak moral dan tidak mengakomodasi keadilan dan bukan karena ia mengadopsi pandangan agama tertentu atau tidak. Dalam hal ini Muhammad Said Al-Asymawi menyebut sebuah hadis yang bermakna bahwa "kerajaan musyrik dapat bertahan sementara kerajaan yang zalim pasti hancur." Di samping itu, jika kita teliti lebih mendalam sesungguhnya substansi syariah tidak berbeda jauh dengan substansi hukum secara umum. Manusia memiliki bahasa dan pemikiran yang bersifat universal, dan universalitas ini mendasari sistem dan pemikiran hukum yang dihasilkannya. Muhammad Said Al-Asymawi menyebutkan bahwa sistem dan isi hukum Mesir sesungguhnya sudah kompatibel dengan syariah sehingga tidak perlu untuk "diislamisasi" lagi. Ketiga, jika pemerintahan Islam mengacu kepada pemerintahan Nabi SAW di Madinah, maka perlu dipahami bahwa pemerintahan Nabi di Madinah adalah bentuk "pemerintahan Tuhan" yang tidak dapat ditiru setelahnya. Kebijakan Nabi dikontrol langsung oleh Tuhan dan oleh karena hampir secara mutlak jauh dari kekeliruan. Setelah itu, semua model pemerintahan adalah pemerintahan sipil atau pemerintahan manusia yang harus dikendalikan lantaran cenderung untuk korup dan sewenang-wenang. Menurut Muhammad Said Al-Asymawi khilafah pasca khulafaurosyidin cenderung menjadi lembaga politik berbasis tribalisme ketimbang nilai keagamaan. Dalam hal ini, teokrasi digunakan sebagai model yang ideal, di mana para penguasa dianggap sebagai pancaran atau manifestasi Tuhan di muka bumi. Model teokrasi adalah model peninggalan Fir'aun di Mesir yang kemudian diadopsi oleh para pendeta di Eropa pada abad pertengangan untuk melegitimasi kekuasaan yang cenderung mutlak dan otoriter. Model ini pula yang kemudian digunakan oleh para penguasa Islam dalam sejarahnya. (Al-Asymawi 2004) ${ }^{26}$

Islam dalam pandangan Muhammad Said Al-Asymawi tidak menyebutkan satu bentuk definitif system politik atau pemerintahan, karena Islam lebih tertarik kepada manusia dan kesadarannya ketimbang kepada system atau aturan hukum tertentu. Sistem politik dan pemerintahan dalam pandangan Islam harus didasari oleh nilai-nilai keadilan dan kemanusiaan

${ }^{26}$ Muhammad Said Al-Asymawi, Menentang Islam Politik, terj. Widyawati (Bandung: Alifya, 2004), 93-100. 
sehingga sistem politik dan pemerintahan sipil-demokratis yang menjadikan rakyat sebagai sumber dan orientasi maslahat kekuasaan politik dalam pandangan Muhammad Said Al-Asymawi lebih dekat ke arah itu ketimbang yang lain. Pemerintahan sipil-demokratis diyakini lebih dapat mendorong kemajuan peradaban, seni, dan kebudayaan serta mendorong Islam sebagai rahmat untuk semua. Pemerintahan sipil-demokratis dianggap dapat menghadirkan Islam sebagai jalan menuju Tuhan dan kemajuan kepada manusia, membuat Islam makin inklusif dan terbuka bagi semua, dan pada saat yang bersamaan, mengakomodasi manusia dalam Islam, menjadikan Tuhan sebagai inti dan poros sementara manusia sebagai tujuan. ${ }^{27}$

Selain hal-hal di atas, kelompok Islam politik mengandalkan slogan, propaganda, dan indoktrinasi untuk menyebarkan pahamnya ke tengah khlayak. Slogan penting kelompok tersebut adalah "kedaulatan hanya milik Tuhan" (la hukm illa lillah). Dalam pandangan Muhammad Sail Al-Asyamawi, penggunaan slogan dan propaganda adalah kekhasan strategi kelompok tirani untuk menguasai massa dengan memanipulasi bahasa dan simbol. Massa biasanya mudah dibangkitkan emosi dan semangat primordialnya dengan penggunaan slogan, yakni sebaris kata-kata menarik yang menutup diri dari telaah kritis. Lebih tragis dan berbahaya lagi jika yang dimanipulasi oleh kelompok tirani tersebut adalah bahasa dan simbol keagamaan, karena sifatnya yang yang nyaris mutlak dan ilahiah. Kelompok tirani itu selain memanipulasi bahasa dan symbol agama, juga mendudukkan diri mereka sebagai juru bicara tuhan, penafsir tunggal kebenaran, sehingga semua kontra tafsir terhadapnya akan otomatis dianggap sebagai bid'ah, kafir, dan menentang agama. Di samping itu kondisi minoritas, terjepit dalam kolonialisme, dan rasa rendah diri yang akut, menjadi lading subur munculnya pandanganpandangan tiranik yang mengukuhkan secara buta slogan "kedaulatan hanya milik Tuhan”. Muhammad Sail Al-Asymawi mencontohkan hal itu dengan pandangan Abul A'la Al-Maududi dalam bukunya The Islamic Government. Buku ini dalam banyak hal mengilhami gerakan-gerakan radikal di banyak Negara, termasuk Mesir. Dalam pandangan Muhammad Sail Al-Asyamawi, pendapat-pendapat Abul A'la Al-Maududi tentang negara dan kedaulatan Tuhan penuh apriori, melupakan telaah kritis, di samping itu, penulisnya mengutip banyak ayat Qur'an tanpa menimbang aspek asbab nuzul ayat dan tanpa merujuk kepada tafsir otoritatif para mufasir besar atas ayat-ayat tersebut, sehingga tidak ilmiah dan tampak demi mengukuhkan pendapat-

${ }^{27}$ Ibid., 103 
pendapat pribadinya semata. Hal yang sama juga tejadi pada Sayyid Quthb dengan bukunya Maalim fit Thariq. Teori-teori Islam politik dalam kedua buku tersebut, dalam pandangan Muhammad Said Al-Asymawi, menjadi bahan kelompok tirani untuk mendoktrin massa dan menggerakkan kekerasan. ${ }^{28}$

Slogan "kedaulatan hanya milik Tuhan" (la hukm illa lillah) oleh karena itu adalah slogan politik kelompok tirani untuk merebut kekuasaan yang sama sekali tidak ada hubungannya dengan ajaran Islam yang otentik. Ia adalah reproduksi slogan dan stretegi kelompok khawarij di era setelahnya yang kemudian diadopsi oleh para rezim khilafah dan gerakan-gerakan takfiri di dunia muslim. Untuk mengatasi itu, menurut Muhammad Said Al-Asymawi, di antaranya adalah merevitalisasi model penafsiran ayat yang selalu merujuk kepada sebab khusus turunnya ayat, al-ibrah bi khususi sabab la bi umumil lafdzdi, sehingga terhindar dari manipulasi dan penafsiran yang literalis. Asbab Nuzul QS. Al-Maidah Ayat 44-48, ayat-ayat yang dijadikan dalih kelompok tirani untuk mengkampanyekan slogan "kedaulatan hanya milik Tuhan" (la hukm illa lillah), terkait erat dengan perilaku khusus orang-orang Yahudi di Madinah yang menolak menerapkan hukuman rajam bagi pezina meskipun hukuman tersebut merupakan aturan dalam agama Yahudi. Makna yahkum dalam QS. Al-Maidah Ayat 44-48 pun adalah "memutus perkara" dan tidak dapat dimaknai dengan pengertian "hukum atau pemerintahan modern". Kelompok tirani condong menggunakan penafsiran literalis karena makna ayat dapat ditarik sejauh mungkin mengikuti selera serta kepentingan politik yang ia usung. Di samping itu, karena Quran adalah kita yang terpadu, penafsiran sebuah ayat harus selalu dikaitkan dengan ayat-ayat lain, sehingga dapat ditarik makna yang tidak parsial. Bahaya akibat pembacaan politis dan parsial terhadap Qur'an, menurut Muhammad Said Al-Asymawi, pernah dikeluhkan oleh Sahabat Ibu Abbas lewat perkataannya: "Al-Qur'an diturunkan kepada kita, setiap kali kita membaca ayat-ayatnya, kita mengetahui apa yang ada di balik ayatayat tersebut. Tetapi sepeninggal kita, akan muncul orang-orang yang terus membaca ayat-ayat tersebut sembari melupakan konteks turunnya. Inilah yang memicu pemahaman yang berbeda serta perselisihan yang merusak". ${ }^{29}$

\footnotetext{
${ }^{28}$ Ibid., 35-37.

${ }^{29}$ Ibid., 52-55.
} 


\section{PENUTUP}

Muhammad Said Al-Asyamawi adalah seorang universalis dan humanis. Universalis dalam arti lebih melihat dan mementingkan aspek universal ajaran agama, bahwa agama apa pun namanya akan diturunkan sebagai jalan keselamatan dan bukan sumber perpecahan dan penderitaan. Oleh karena itu, baginya misi suci agama tidak boleh direduksi dan dimanipulasi menjadi politik yang berorientasi kekuasaan dan temporalitas. Ada satu ungkapan yang sering diulang oleh Muhammad Said Al-Asymawi terkait itu yakni: Tuhan menginginkan Islam menjadi agama, namun manusia menjadikannya sebagai politik. Humanis dalam arti memiliki pemihakan terhadap manusia dan nilai-nilai kemanusian, bahwa manusia lepas dari atribut kebangsaan, budaya, keagamaan mereka, merupakan makhluk yang mulia dan oleh karena itu harus dimulyakan. Manusia memiliki kehormatan dan hak-hak dasar yang harus ditegakkan dan dijunjung tinggi sehingga penjajahan dan penindasan satu manusia ke manusia lain harus diakhiri. Bagi Muhammad Said Al-Asyamawi kebenaran dan kemanfaatan dari mana pun datangnya, Barat atau Timur, harus diapresiasi dan diterima sebagai peradaban manusia. Dalam hal ini, oleh karenanya, menurut penulis, tidak tepat jika kita menggolongkan Muhammad Said Al-Asymawi sebagai pemikir liberal dan pro-Barat. Pemikirannya berangkat dari kepakarannya terhadap turats dan khazanah ilmu-ilmu keislaman. Penguasaannya yang mendalam terhadap ilmu agama, menjadikannya seorang yang terbuka dan universalis. Kritik Muhammad Said Al-Asmawi terhadap wawasan yang picik dari para pemikir umat Islam tidak lantas berarti dia pro-Barat, kritiknya terhadap pemikiran umat Islam merupakan empati dan upaya emansipasinya agar umat Islam dapat mengatasi krisisnya dan mengejar ketertinggalannya sehingga dapat sejajar dengan peradaban lain.

Tema siyasah atau politik termasuk dalam lingkup pembahasan muamalah. Konsep dan terma-terma fiqih siyasah Islam klasik memang banyak yang telah kehilangan konteks dan relevansinya di dunia modern, bahkan beberapa cenderung probematis dan bermasalah jika diterapkan di dunia kontemporer. Problem yang semacam itu disebabkan oleh beberapa hal. Pertama, Fiqih siyasah lahir dan dirumuskan dalam suasna imperium kerajaan Islam dari Dinasti Umayah, Dinasti Abbasiyah, hingga Dinasti Utsmaniyah, sehinga konsep dan isinya sangat bias dinasti dan cendeung memperkuat posisi amir dan kerajaan. Kedua, politik adalah disiplin yang dinamis dan terus berkembang menyesuaikan konteks dan kebutuhan, 
sehingga kajian terhadapnya selalu mengalami dinamika dan transformasi. Ketiga, politik merupakan bidang ijtihad yang terus berkembang. Keempat, dunia Islam mengalami degradasi pemikiran yang lumayan lama sehingga kurang muncul pemikir-pemikir baru dengan pemikiran yang lebih segar dan kontekstual. Diperlukan kebangkitan intelektual di bidang fiqih siyasah dengan cara mendekonstruksi dan kemudian merekonstruksi disiplin fiqih siyasah sehingga dapat menyumbang banyak hal bagi kehidupan masyarakat modern di dunia internasional. ${ }^{30}$ Upaya tersebut dimungkinkan di antaranya dengan kembali mendasarkan konsep dan pemahaman fiqih siyasah kepada maqashid syariah sebagai inti dan tujuan hukum dalam Islam. Apa yang telah dipikirkan dan dilakukan oleh Muhammad Said Al-Asymasi ada dalam kerangka itu, di mana dia berkali-kali menegaskan bahwa pemahaman kita terhadap agama dan politik harus berangkat dari otensitas ajaran Islam serta pengetahuan yang memadai pada aspek sejarah, agar agama terhindar dari manipulasi dan distorsi dari pandangan dan kelompok "Islam politik". Di sisi yang lain, fiqih membuka ruang yang leluasa bagi munculnya pemikiran baru termasuk dalam bidang siyasah.

${ }^{30}$ Tim Forza Pesantren, Ijtihad Politik Islam Nusantara: Membumikan Fiqih Siyasah melalui Pendekatan Maqashid asy-Syariah (Kediri: Lirboyo Press, 2015), 10-12 


\section{DAFTAR PUSTAKA}

Al-Asymawi, Muhammad Said. Menentang Islam Politik. Dialihbahasakan oleh Widyawati. Bandung: Alfiya, 2004.

, Muhammad Said. Jihad Melawan Islam Ekstrem. terj. Hery Haryanto Azumi. Depok: Desantara, 2002.

, Muhammad Sa'id. UsuI asy-Syari'ah. Beirut: al-Maktabah alTsaqafiyyah, 1992.

Azhar, Muhammad. "Etika Politik Mohammed Arkoun." Ishraqi, Vol. 10, No. 1, Juni 2012 10, no. 1 (Juni 2012).

Azra, Azyumardi. "Distinguishing Indonesian Islam: Some Lesson to Learn" Islam in Indonesia: Contrasting Images and Interpretations." In Islam in Indonesia: Contrasting Images and Interpretations, by Jajat Burhanudin, edited by "Distinguishing Indonesian Islam: Some LesKees Van Dijk Azyumardi Azra, 2. Amsterdam: Amsterdam Universitty Press, 2013. Who's Who in The Arab World. Biographycal Dictionary 1986-1987. Beirut, Libanon: Publitec Publication bekerjasarna dengan Bntt.envorih And Co (Publisher) LTD Inggris, tt.

Halim, Abdillah. "Fatwa Dan Politisasi Agama (Analisis Wacana Penggunaan Fatwa Pada Pilkada DKI Jakarta)." An-Nuha: Jurnal Kajian Islam, Pendidikan, Politik, Budaya Dan Sosial 5, no. 2 (Desember 2018): 231-259.

Jati, Wasisto Raharjo. "AGAMA DAN POLITIK: Teologi Pembebasan Sebagai Arena Profetisasi Agama." Walisongo 22, no. 1 (2014): 133-156.

Kymlicka, Will. Politics in the Vernacular: Nationalism, Multiculturalism, and Citizenship. Oxford: Oxford University Press, 2001.

Lobban, Carolyn, and Fluehr. Melawan Ekstremisme Islam, Kasus Muhammad Sa'id al-Asymawi”. Translated by Haryanto Azumi. Depok: Desantara, 2002.

Esposito, John L., and John O. Voll. Demokrasi di Negara-Negra Muslim: Problem \& Prospek. Translated by Rahamni Astuti. Bandung: Mizan, 1999.

Mohammad, Goenawan. "Kaca”, Catatan Pinggir 4. Jakarta: Grafiti, 1999.

Sagiv, David. Fundamentalism and Intelectuals in Fgypt 1971-1993. London: Frank Cass, 1995.

Tim Forza Pesantren. Ijtihad Politik Islam Nusantara: Membumikan Fiqih Siyasah melalui Pendekatan Maqashid asy-Syariah. Kediri: Lirboyo Press, 2015. 